\title{
Protocol Approval Date
}

National Cancer Institute

\section{Source}

National Cancer Institute. Protocol Approval Date. NCI Thesaurus. Code C132352.

Date protocol that was finalized or approved internally by the sponsor. 